\title{
METODOLOGI KRITIK MATAN HADIS MENURUT AL-ADLABIDARI TEORI KE APLIKASI
}

\author{
Hairul Hudaya \\ Dosen Hadis dan Ilmu Hadis Fakultas Tarbiyah \\ IAIN Antasari Banjarmasin \\ Email: hud hud05@yahoo.com
}

\begin{abstract}
The validity of hadith is not only seen from the sanad aspect, but also from matan. Hadith scholars set two criteria for the validity of the matan, both are avoid syaz and illah. Disability element of matan at syaz lies in the contention of the matan. The 'illah aspect of matan was because of the additional editorial matan when compared with other. AlAdlabi formulated the criteria of the validity of matan based on four things namely; 1). It is not contradicting with the Koran; 2). It is not contrary with the valid hadith and sirah nabawiyah; 3). It is not contrary to reason, sense and history; and 4). It is similar with the prophetic word. If the formula of al-Adlabi's matan criticism is seen in aspects of syaz and illah, then it appears that his offering is only covers one aspect of the syaz of matan criticism. While the criteria of illah have not been accommodated in the rule.
\end{abstract}

Kata kunci: matan sahih, syaz, 'illah,

\section{Pendahuluan}

Ulama menetapkan bahwa hadis terdiri dari dua komponen utama yakni sanad dan matan. Mereka juga menetapkan kaedah-kaedah yang digunakan untuk mengukur tingkat akurasi dan validitas hadis melalui kedua komponen tersebut. Dalam hal sanad, tiga kriteria penentuan validitas sanad dimunculkan yakni pertama, kontinuitas transmisi periwayatan, kedua, perawi yang adil dan dhabit ketiga, terhindar dari syadz dan illah. ${ }^{1}$ Khusus kritik matan, ada dua variabel yang digunakan yakni terhindar dari syadz dan illah. Pembagian kaedah tersebut mengisyaratkan bahwa antara sanad dan matan memiliki kriteria sendiri dalam penentuan validitas hadis. Karenanya muncul adagium yang menyatakan bahwa hadis dengan sanad yang sahih tidak mesti matannya juga sahih. Begitu pula sebaliknya. $^{2}$

Karena hadis sangat mengandalkan jalur periwayatan sebagai mata rantai pembawa berita maka kajian dan praktek keilmuan di bidang kajian sanad berkembang pesat dan dijadikan landasan awal dalam menentukan kualitas periwayatan. Keadaan ini memunculkan pandangan bahwa ulama hadis hanya menyandarkan penilaian otentisitas riwayat pada kritik sanad ansich dan mengabaikan penelitian unsur terpenting yang dibawa sanad yakni matan. ${ }^{3}$ Penilaian demikian mendapat sejumlah bantahan dikalangan ulama hadis yang mengatakan bahwa meskipun penelitian hadis sangat mengandalkan

\footnotetext{
${ }^{1}$ M. Syuhudi Ismail, Metodologi Penelitian Hadis Nabi, (Jakarta: Bulan Bintang, 1992), h. 73-74.

${ }^{2}$ Shubhi al-Shalih, Ulum al-Hadis wa Mushthalahuhu, (Beirut: Dar al-'Tlm li al-Malayin, 1988), cet. XVII, h. 279.

${ }^{3}$ Ahmad Amin, misalnya, mengatakan bahwa para ulama hadis hanya memperhatikan kritik ekstren (sanad) namun tidak mengkaji kritik intern (matan). Dalam kritik hadis, mereka telah sampai mengkaji perawi dari jarh dan ta'dil. Dengan ilmu tersebut mereka mengkritik para perawi hadis apakah tsiqah atau tidak dan sejauh mana tingkat ketsiqahannya. Begitu pula mereka telah mengkaji apakah seorang perawi bertemu dengan gurunya atau tidak. Lihat Ahmad Amin, Dhuba al-Islam, (Kairo: Maktabah al-Nahdhah al-Mishriyyah, 1974), jld. II, h. 130.
} 
penilaian akan kualitas periwayat atau sanad namun demikian para ulama tidak meninggalkan penelitian matan. Untuk maksud pembuktian tersebut para ulama menulis sejumlah karya yang berbicara tentang metode kritik matan meski dalam jumlah yang sangat terbatas bila dibanding dengan kajian metode kritik sanad. Salah satu karya yang membahas tentang metode kritik matan adalah yang ditulis oleh Shalah al-Din Ahmad al-Adlabi.

Makalah ini berusaha membahas tentang metode kritik matan hadis menurut al-Adlabi dan aplikasinya dalam mengkritik matan hadis.

\section{Biografi Singkat Al-Adlabi}

Penulis tidak menemukan penjelasan lebih luas mengenai biografi al-Adlabi. Hasil dari pelacakan melalui berbagai situs internet hanya diperoleh informasi bahwa namanya adalah Salah al-Din alAdlabi. Ia menulis kitab Kasyf al-Malul atau disebut dengan Silsilah al-Ahadis al-Sabihab dan kitab yang tengah dibahas yakni Manhaj Naqd al-Matn Inda Ulama al-Hadis al-Nabawi. Ia memperoleh gelar Doktor dalam bidang Ilmu Islam dan Hadis dari Dar al-Hadis al-Hasiniyyah di Magribi. Iamengajar hadis di fakultas Dirasah Islamiyah Dubai, mengajar hadis dan ilmu hadis di Universitas Muhammad ibn Sa'ud Riyad dan dosen pada fakultas Bahasa Arab di Maroko. ${ }^{4}$

\section{Metode Kritik Matan Menurut Ulama Hadis}

Dalam menentukan kesahihan hadis, para mubadditsin menetapkan tiga kriteria kesahihan pada sanad dan dua kriteria kesahihan matan. Dua kriteria kesahihan hadis pada matan tersebut adalah terbebasnya matan hadis dari unsur syadz dan illah. ${ }^{5}$ Dalam hal syadz, ulama berbeda dalam mendefinisikannya. Setidaknya ada tiga ulama yang memiliki definisi berbeda mengenai istilah syadz yakni al-Syafi', al-Hakim dan al-Khalili. Imam al-Syafi'i mendefinisikannya sebagai hadis yang diriwayatkan oleh seorang tsiqah yang bertentangan dengan hadis yang diriwayatkan oleh orangorang (perawi tsiqah lainnya). ${ }^{6}$ Al-Hakim mendefinisikannya dengan 'hadis yang diriwayat oleh seorang tsiqah secara menyendiri tanpa perawi tsiqah lainnya dan hadis tersebut tidak memiliki mutabi' sama sekali'. ${ }^{7}$ Sementara Abu Ya'la al-Khalili mendefinisikan dengan 'hadis yang tidak punya sanad kecuali hanya satu yang periwayatnya menyendiri dengan sanad itu, baik ia berstatus siqah atau tidak. Jika tidak siqah maka disebut hadis matruk tidak diterima, kalau statusnya siqah maka tawaqquf dan tidak berhujjah dengannya'. ${ }^{8}$ Ketiga definisi tersebut, secara esensial sangat berbeda. Al-Syafi'i menekankan

${ }^{4}$ http://cb.rayaheen.net/showthread.php?tid=13819

${ }^{5}$ Menurut Ibn Shalah, hadis dinilai sahih apabila memenuhi persyaratan berikut; hadis bersambung sanadnya (sampai kepada Nabi), diriwayatkan oleh (periwayat) yang adil dan dhait sampai akhir sanadnya, tidak mengandung kejanggalan (syadz) dan kecacatan ('illah). Lihat, Ibn Shalah, Muqaddimah Ibn Shalah fi 'Ulum al-Hadis, (Beirut: Dar al-Kutub al-'Ilmiyyah, 1979), h. 78. Sedang Imam al-Nawawi meringkas definisi di atas dengan rumusan: Hadis yang bersambung sanadnya, diriwayatkan oleh orang yang adil dan dhabit serta tidak mengandung kejanggalan dan kecacatan. Lihat, al-Suyuthiy, Tadrib al-Rami fi Syarh Taqrib alNawawi, Juz I, (Beirut: Dar al-Fikr, 1988), h. 63.

'Imam Syafi'i menyatakan: "Syadz bukan berarti perawi yang tsiqah meriwayatkan suatu hadis namun tidak diriwayatkan oleh perawi lainnya, akan tetapi syadzadalah hadis yang diriwayatkan oleh sejumlah perawi tsiqah yang bertentangan dengan seorang perawi tsiqah lainnya". dalam kasus ini dicontohkan adanya pertentangan seorang perawi yang meriwayatkan hadis dalam bentuk qauliyah sedang para perawi tsiqah lainnya meriwayatkannya dalam bentuk fi'liyah. Lihat, Muhammad 'Ajjaj al-Khatib, Ushul al-Hadis: 'Ulumubu wa Mushthalahuhu, (Beirut: Dar al-Fikr, 1989), h. 347.

${ }^{7}$ Muhammad ibn Abdullah al-Hakim al-Naisaburi, Ma'rifah 'Ulum al-Hadis, (Haidar Abad: Dairah al-Ma'arif al-Usmaniyyah, t.th), h. 119.

${ }^{8}$ Abu Ya'la Ibn al-Khalili al-Qazwini, al-Irsyad fi Ma'rifah Ulum al-Hadis, (Riyadh: Maktabah al-Rasyad, 1989), juz. 1, h. $176-177$. 
syadz pada pertentangan dua jalur periwayatan antara rawi siqah dengan para perawi yang lebih siqah sementara al-Hakim dan al-Khalili menekankan pada tafarrudnya perawi atau penyendirian perawi secara mutlak. Konsekwensinya, Al-Syafi'i tidak memandang syadz hadis fard atau ahad sedang alHakim dan al-Khalili memutlakkannya sebagai syadz. Para ulama belakangan, mayoritas mengikuti definisi al-Syafi'i dalam menilai hadis syadz.

Sedang 'illah hadis berarti ilmu yang membahas sebab-sebab tersembunyi yang dapat mencacatkan kesahihan hadis baik dikarenakan mewashakan yang munqathi', memarfu'kan yang mauquf atau memasukkan hadits pada hadis lainnya dan lainnya. Dari pengertian ini dapat disimpulkan bahwa illah hadis memiliki dua syarat yakni ketersembunyian dan dapat mencacatkan hadis yang shahih. Jika salah satu dari syarat tersebut tidak ditemukan, seperti cacat yang terdapat pada hadis tersebut sangat jelas atau tidak mencacatkan hadis, maka tidak dapat disebut dengan 'illah.'

Arifuddin Ahmad menyebutkan unsur kaidah minor syadz dan 'illah pada matan hadis. Kaedah minor terbebasnya matan dari unsur syadz, diantaranya adalah 1. Sanad hadis bersangkutan tidak menyendiri; 2. Matan hadis bersangkutan tidak bertentangan dengan matan hadis yang sanadnya lebih kuat; 3 matan hadis bersangkutan tidak bertentangan dengan al-Qur'an; dan 4. Matan hadis bersangkutan tidak bertentangan dengan akal dan fakta sejarah. ${ }^{10}$

Sedang kaidah minor bagi matan hadis yang mengandung illah adalah 1. Matan hadis bersangkutan tidak mengandung idraj (sisipan); 2. Matan hadis bersangkutan tidak mengandung riyadah (tambahan); 3. Tidak terjadi maqlub (pergantian lafal atau kalimat) bagi matan hadis bersangkutan; 4. Tidak terjadi idhthirab (pertentangan yang tidak dapat dikompromikan) bagi matan hadis bersangkutan; dan 5. Tidak terjadi kerancuan lafal dan penyimpangan makna yang jauh dari matan hadis bersangkutan. Jika illah hadis itu mengandung pertentangan dengan hadis lain yang lebih kuat, maka matan hadis tersebut sekaligus mengandung syudzudz: ${ }^{11}$

Al-Adlabi sendiri ketika meneliti kaedah ke íllaban hadis yang diuraikan oleh al-Hakim dalam kitab al-Ma'rifahnya berkenaan dengan kritik matan menyatakan bahwa dari kesepuluh jenis 'illah yang disebut al-Hakim semua merujuk kepada sanad dan bukan matan. Illah-illah tersebut, menurutnya tidak mencacatkan kesahehan matan kecuali 'illah yang kesepuluh, yaitu memarfu'kan yang mauquf. Sedang unsur kritik matan dalam kaedah syadz hadis, ketika ia meneliti contoh syadz yang dikemukakan al-Hakim, menyatakan bahwa dari tiga contoh syadz hanya ada dua yang berkenaan dengan kritik matan. Pertama, karena unsur pertentangannya dengan hadis yang lebih sahih dan lebih tsiqah dan kedua, karena adanya kalimat yang berbeda dengan riwayat lain. Kalimat tersebut pun ternyata tidak bertentangan dengan riwayat para tsiqah namun justru sejalan. ${ }^{12}$

Berdasarkan pandangan di atas, al-Adlabi sesungguhnya ingin menyatakan bahwa meski ulama hadis memuat teori tentang kritik matan dalam penelitian kesahihan hadis terutama pada kaedah syadz dan illah namun dalam prakteknya tidak ditemukan secara tegas metode kritik matan hadis. AlAdlabi kemudian menyebutkan sembilan kajian dalam ilmu hadis yang berkenaan dengan kaedah kritik matan menurut ulama hadis yakni; hadis syadz, hadis munkar, hadis mu'all, hadis mudhtharib, hadis mudraj, hadis maqlub, hadis maudhu' dan tanda-tandanya, perkataan sahabat mengenai masalah yang tidak menjadi wilayah akal dan mengetahui orang yang diterima riwayatnya dan yang ditolak. ${ }^{13}$

\footnotetext{
${ }^{9}$ Mahmud al-Thahhan, Taysir Mushthalah al-Hadits, (Beirut: Dar al-Fikr, tth), h. 83

${ }^{10}$ Arifuddin Ahmad, Paradigma, h. 108.

${ }^{11}$ Arifuddin Ahmad, Paradigma, h. 109.

${ }^{12}$ Shalah al-Din Ahmad al-Adlabi, Manhaj, h. 186.

${ }^{13}$ Shalah al-Din Ahmad al-Adlabi, Manbaj, h. 192-222.
} 
Munculnya berbagai perbedaan dalam memahami kritik matan hadis terutama dari sudut metodologis sangat memungkinkan karena berbagai faktor diantaranya: 1. Kaedah kritik matan hadis tersebar dalam beberapa ulasan mengenai kualitas hadis, 2. Belum banyaknya karya yang membahas secara khusus tentang metode kritik matan hadis, 3. Kaedah-kaedah kesahehan hadis terdahulu belum mencakup seluruh persoalan berkenaan dengan metode kritik matan.

Sebagaimana disebutkan di atas, pembahasan metode kritik matan, menurut al-Adlabi, tersebar pada berbagai kajian ilmu hadis, para ulama belakangan menggabungkan berbagai kriteria untuk menetapkan kaedah kritik matan hadis. Diantara kaedah kritik matan adalah syadz, illah, tanda-tanda hadis maudhu dan kriteria hadis maqbul.

Para ulama hadis menyebutkan secara berbeda beberapa tanda hadis palsu dari segi matan. Diantara ciri-ciri kemaudhu'an hadis adalah:

Pertama, adanya qarinah pada matan (bukti-bukti yang mengiringi matan) baik rusak (rakik) pada makna maupun lafal atau keduanya. Kedua, bertentangan dengan akal sehat yang tidak memungkinkan untuk di takwil atau bertentangan dengan indera. Ketiga, hadis tersebut bertentangan dengan dalil qur'an yang qathi' atau hadis mutawatir, ijma' yang tidak memungkinkan untuk di jama'. Keempat, hadisnya terlalu berlebihan dalam menilai amal. Kelima, hadis yang mestinya disaksikan oleh banyak perawi sahabat namun tidak masyhur dan hanya diriwayatkan sedikit perawi. Keenam, hadis yang bertentangan dengan hikmah, dan logika yang lurus. Ketujuh, hadis yang diriwayatkan oleh penganut rafidhah. Kedelapan, bertentangan dengan kebenaran fakta sejarah. Kesembilan, salah seorang perawinya mengaku bertemu dengan perawi lainnya, padahal secara logika tidak mungkin mereka bertemu. Kesepuluh, pengakuan sebagian kalangan sufi yang menyatakan bertemu dengan Nabi melalui kasyaf tanpa sanad yang sahih dan bersambung atau melalui mimpi. ${ }^{14}$

\section{Metode Kritik Matan Menurut Al-Adlabi}

Tolok ukur yang digunakan dalam kritik matan tidak lepas dari unsur syadz dan illah dalam kaedah kesahehan hadis. Menurut al-Khatib al-Bagdadi (w. 463 H/ 1072 M) bahwa suatu matan hadis dapat dinyatakan maqbul sebagai matan hadis yang sahih apabila memenui unsur-unsur sebagai berikut:

1. Tidak bertentangan dengan akal sehat;

2. Tidak bertentangan dengan hukum al-Qur'an yang telah muhkam (ketentuan hukum yang telah tetap);

3. Tidak bertentangan dengan hadis mutawatir;

4. Tidak bertentangan dengan amalan yang telah menjadi kesepakatan ulama masa lalu (ulama salaf);

5. Tidak bertentangan dengan dalil yang telah pasti; dan

6. Tidak bertentangan dengan hadis ahad yang kualitas kesahihannya lebih kuat.

Tolok ukur yang dikemukakan di atas, hendaknya tidak satupun matan hadis yang bertentangan dengannya. Sekiranya ada, maka matan hadis tersebut tidak dapat dikatakan matan hadis yang sahih. ${ }^{15}$

${ }^{14}$ Muhammad Muhammad Abu Zahwu, al-Hadis wa al-Muhadditsun, (Beirut: Dar al-Fikr al-'Araby, t.th), h. 482. Nur alDin 'Itr, menyebutkan empat ciri hadis maudhu' yang termuat dalam ciri-ciri di atas. Lihat, Nur al-Din 'Itr, Manhaj al-Naqd $f i$ 'Ulum al-Hadis, (Beirut: Dar al-Fikr, tth), diterjemahkan oleh Mujiyo, 'Ulum al-Hadit, (Bandung: Rosdakarya, 1997), cet. II, jld, II, h. 82. Muhammad Hasbi ash-Shiddieqy menyebut enam ciri kemaudhu'an hadis. Lihat, al Muhammad Hasbi ash-Shiddieqy, Sejarah dan Pengantar Ilmu Hadis, (Semarang: Pustaka Rizki Putra, 1997), h. 215. 
Hamzah Abu al-Fath mengemukakan beberapa kaedah-kaedah penting untuk mengetahui kualitas kesahehan matan. Diantara kaedah tersebut adalah:

1. Membandingkan sunnah dengan Qur'an

Al-Qur'an merupakan sumber hukum pertama dalam Islam, sehingga apabila ditemukan hadis yang bertentangan dengannya maka dinilai sebagai hadis dhaif dan ditolak. Kenyataan ini tidak menunjukkan adanya pertentangan antara keduanya karena baik al-Qur'an maupun sunnah yang sahih sama-sama berasal dari Allah sehingga tidak mungkin bertentangan. Ada beberapa faktor yang menyebabkan munculnya pertentangan tersebut yakni:

a. Perawi keliru atau lupa dalam meriwayatkan hadis

b. Terdapat perawi yang hilang dalam meriwayatkan hadis

c. Tidak memahami maksud dari perkataan Nabi.

Namun demikian, perlu dicatat bahwa pertentangan tersebut merupakan pertentangan yang bersifat mutlak dimana tidak terdapat jalan untuk mendamaikan antara nash al-Qur'an dan hadis dengan cara jama' atau lainnya.

2. Membandingkan sunnah dengan sunnah.

Ada beberapa kemungkinan terjadinya pertentangan antara satu hadis dengan lainnya, yakni:

a. Terjadinya kesalahan dalam periwayatan

b. Hadis tersebut diriwayatkan secara makna dan berlanjut pada beberapa perawi selanjutnya sehingga jauh dari nash yang sesungguhnya diucapkan Nabi.

c. Perawi memarfu'kan perkataan seorang perawi lainnya.

3. Membandingkan beberapa riwayat hadis yang satu dengan lainnya.

Upaya ini dilakukan untuk mengetahui kualitas suatu hadis dengan cara mengamati berbagai jalur sanad hadis, meneliti dan menetapkan kualitasnya. Dengan ini pula dapat diketahui apakah pada hadis tersebut terdapat idhthirab, qalb, idraj, tashhif, tahrif atau ziyadah.

4. Membandingkan matan hadis dengan peristiwa dan fakta sejarah.

Fakta sejarah merupakan sarana yang sangat penting yang digunakan ulama hadis untuk mengetahui kesahihan dan kedhaifan hadis. Ketika sejarah digunakan sebagai tolok ukur untuk menilai kualitas kesahihan hadis maka fakta sejarah tersebut disyaratkan memiliki tingkat kebenaran faktual dan meyakinkan.

5. Mengamati lafal dan makna hadis.

Dalam hal ini, ada beberapa aspek yang perlu dikaji yakni:

a. Lafal dan makna hadis yang rusak

b. Pertentangan hadis dengan dasar hukum syar'i

c. Hadis memuat hal yang munkar dan mustahil

6. Aspek kognitif dalam periwayatan hadis.

Dalam periwayatan hadis, aspek kognitif digunakan dalam empat hal yakni:

a. Saat mendengar hadis, para ulama mensyaratkan agar seorang perawi dapat membedakan dan memahami hadis yang ia dengar.

b. Saat meriwayatkan hadis, mereka melarang meriwayatkan hadis dhaif terlebih maudhu' kecuali menjelaskan letak kedhaifan dan kemaudhu'annya.

c. Saat menilai perawi, para ulama sering menilai jarh terhadap perawi yang meriwayatkan hadis munkar. 
Saat menilai kualitas suatu hadis, dalam hal ini akal diberi porsi sebagaimana mestinya. ${ }^{16}$

Ibn Qayyim (691 H-751 H) menguraikan lebih jauh kriteria ditolaknya suatu matan hadis yang dengannya dapat diketahui kemaudhu'an hadis tersebut. Beberapa kriteria ada yang sesuai dengan apa yang dikemukakan al-Bagdadi namun sebagian besar lainnya merupakan kriteria yang berbeda. Kriteria tersebut adalah:

1. Memuat balasan dan ancaman yang berlebihan, yang tidak mungkin disabdakan oleh Rasulallah saw.

2. Memuat hal-hal yang diingkari oleh indra

3. Terlalu longgar isinya dan membius

4. Bertentangan secara nyata dengan sunnah yang sharih (menunjukkan arti yang jelas)

5. Menunjukkan bahwa Nabi saw melakukan sesuatu yang jelas dihadapan seluruh sahabat dan semuanya sepakat untuk menyembunyikannya, tidak meriwayatkannya.

6. Hadis itu batal dalam dirinya sendiri. Hal ini jelas menunjukkan bahwa ia bukan sabda Nabi saw

7. Redaksinya tidak mirip dengan sabda para nabi, apalagi sabda Nabi saw yang merupakan wahyu

8. Di dalam hadis itu ada sejarah begini begini

9. Lebih mirip dengan keterangan thabib

10. Dibatalkan isinya oleh sejumlah bukti kuat

11. Bertentangan dengan ayat al-Qur'an yang sharih

12. Disertai oleh sejumlah indikasi yang menunjukkan kebatalannya. ${ }^{17}$

Dari beberapa kriteria yang dikemukakan oleh Ibn Qayyim dan al-Bagdadi di atas al-Adlabi kemudian meringkasnya dan mengajukan empat kriteria kritik matan hadis yang maqbul yakni:

1. Tidak bertentangan dengan al-Qur'an al-Karim

2. Tidak bertentangan dengan hadis dan sirah nabawiyah yang sahih

3. Tidak bertentangan dengan akal, indera dan sejarah

4. Mirip dengan sabda kenabian ${ }^{18}$

Apabila disimpulkan, definisi kesahihan matan hadis menurut mereka, adalah sebagai berikut: pertama, sanadnya sahih; kedua, tidak bertentangan dengan hadis mutawatir atau hadis ahad yang sahih; ketiga, tidak bertentangan dengan petunjuk al-Qur'an; keempat, sejalan dengan alur akal sehat; kelima, tidak bertentangan dengan sejarah, dan keenam, susunan pernyataannya menunjukkan ciriciri kenabian. ${ }^{19}$

\section{Contoh Aplikasi Kritik Matan Hadis Al-Adlabi}

Berdasarkan empat kriteria kesahihan matan yang diajukan al-Adlabi maka berikut akan diuraikan contoh masing-masing kriteria yakni:

\footnotetext{
${ }^{15}$ Bustamin dan M. Isa H.A. Salam, Metodologi Kritik Hadis, (Jakarta: Raja Grafindo Persada, 2004), h. 63.

${ }^{16} \mathrm{Hamzah}$ Abu al-Fath bin Husain Qasim al-Na'imi, al-Manhaj al-Tlmy li al-Ta'amul ma'a al-Sunnah al-Nabawiyyah 'Inda alMuhadditsin, (Oyardon: Dar al-Nafais, 1999), h. 92.

${ }^{17}$ Shalah al-Din Ahmad al-Adlabi, Manhaj Naqd al-Matn 'Inda 'Ulama al-Hadis al-Nabawi, (Beirut: Dar al-Afaq al-Jadid, 1983), h. 237-8.

${ }^{18}$ Shalah al-Din Ahmad al-Adlabi, Manhaj Naqd al-Matn, h. 277-8.

${ }^{19}$ Bustamin dan M. Isa H.A. Salam, Metodologi, h. 64.
} 
Pertama, Kriteria Hadis karena bertentangan dengan al-Qur'an.

Al-adlabi memberikan salah satu contoh hadis yang menurut sebagian ulama bertentangan dengan dalil al-Qur'an. Hadis tersebut berbicara tentang sihir yang menimpa Nabi dan dilakukan oleh orang Yahudi sehingga beliau seakan-akan melakukan sesuatu padahal sebenarnya beliau tidak melakukan sesuatu. Hadis tersebut terdapat dalam sahih Bukhari kitab JizyabbabHal yu'fa min aldzimmi idza sabira, no. 2939 yang berbunyi:

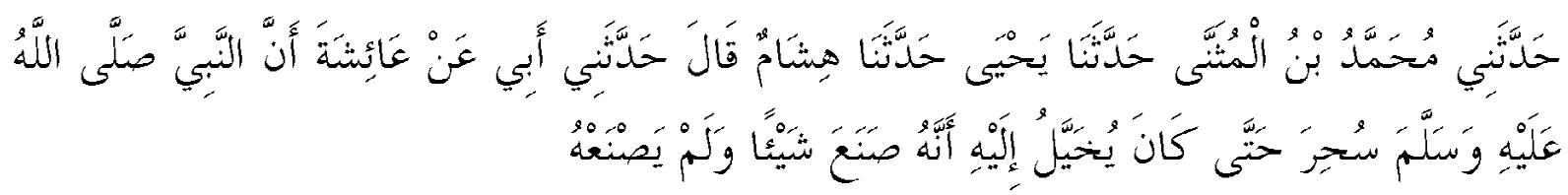

Artinya: Meriwayatkan kepada saya Muhammad bin al-Mutsanna, meriwayatkan kepada kami Hisyam, ia berkata, ayahku meriwayatkan padaku dari 'Aisyah bahwa Nabi saw disibir sampai-sampai beliau merasa melakukan sesuatu padahal tidak melakukannya.

Hadis yang berbicara tentang hal tersebut juga terdapat dalam Sahih Muslim kitab al-salam no. 4059, Sunan Ibn Majah kitab al-tibb no. 2535, Musnad Ahmad bin Hanbal kitab baqi musnad alAnshar no. 23104, 23165, 23211, 23509. ${ }^{20}$

Sebagian ulama yang menolak kesahihan hadis ini, menurut al-Adlabi, karena dinilai bertentangan dengan firman Allah swt: "Dan orang-orang yang dhalim itu berkata: Kamu sekalian tidak lain hanyalah mengikuti seorang lelaki yang kena sibir. Perhatikanlah, bagaimana mereka membuat perbandingan-perbandingan tentang kamu, lalu sesatlah mereka, mereka tidak sanggup (mendapatkan) jalan (untuk menentang kerasulan)." (QS. al-Furqan: 8-9).

Ada beberapa alasan mengapa mereka menolak kesahihan hadis di atas, diantaranya: pertama, hadis di atas membenarkan perkataan kaum musyrik yang mengatakan bahwa 'kamu sekalian tidak lain hanyalah mengikuti seorang lelaki yang kena sibir'. Kedua, menghilangkan kepercayaan terhadap apa yang dibawa oleh Rasulullah saw. Ketiga, sihir merupakan perbuatan setan dan jiwa-jiwa yang buruk dan keji. Adapun orang-orang yang membentengi diri dengan beribadah kepada Allah tidak akan dapat ditaklukkan oleh para setan dan orang-orang buruk itu. Dalam hal ini, Allah berfirman: "Sesungguhnya hamba-hamba-Ku tidak ada kekuasaan bagimu terhadap mereka, kecuali orang-orangyang mengikuti kamu, yaitu orang-orang yang sesat." (QS. al-Hijr: 42).

Namun argumen-argumen yang menilai lemah hadis di atas dijawab oleh al-Qasimi dengan menggunakan dalil naqli dan aqli sehingga ia menyakini akan kesahihan hadis mengenai tersihirnya Nabi. Al-Adlabi nampaknya sejalan dengan pendapat al-Qasimi yang menyatakan kesahihan hadis di atas namun di sini ia hanya ingin menunjukkan pandangan sebagian orang yang melemahkan hadis sahih karena dinilai bertentangan dengan dalil al-Qur'an. ${ }^{21}$

Kedua, Hadis yang bertentangan dengan hadis dan sirah nabawiyah yang sahih.

Menurut al-Adlabi, ada dua syarat yang harus terpenuhi apabila hendak menolak sebuah riwayat yang marfu' kepada Nabi saw. karena bertentangan dengan hadis lain. Pertama, tidak ada kemungkinan memadukan (al-jam'u). jika dimungkinkan pemaduan di antara keduanya dengan tanpa memaksakan diri, maka tidak perlu menolak salah satunya. Jika di antara keduanya terjadi pertentangan yang tidak mungkin dipadukan, maka harus ditarjih. Kedua, hadis yang dijadikan sebagai dasar untuk menolak

\footnotetext{
${ }^{20}$ CD-ROM Mausu'ah al-Hadis al-Syarif al-Kutub al-Tis'ah, 1997.

${ }^{21}$ Shalah al-Din Ahmad al-Adlabi, Manhaj Naqd al-Matn, h. 255.
} 
hadis lain yang bertentangan haruslah berstatus mutawatir. ${ }^{22}$

Syarat pada poin nomor dua di atas yang menyatakan bahwa suatu hadis dinilai lemah apabila bertentangan dengan hadis mutawatir, menurut al-Adlabi, tidaklah realistis dan mempersempit pembahasan tentang adanya pertentangan di antara hadis-hadis. Menurutnya, para ulama telah memiliki kategori untuk hadis-hadis yang saling bertentangan. Hadis dhaif apabila bertentangan dengan hadis sahih maka disebut dengan hadis munkar. Adapun hadis sahih yang bertentangan dengan hadis yang lebih sahih sanadnya maka disebut hadis syadz: Sedang hadis yang bertentangan dengan hadis mutawatir disebut dengan maudhu' ${ }^{23}$

Salah satu contoh yang dikemukakan al-Adlabi berkenaan dengan adanya pertentangan di antara hadis adalah hadis tentang puasa setelah pertengahan Sya'ban. Dalam Musnad Ahmad bin Hanbal kitab baqi musnad al-muktsirinbabbaqi al-musnad al-sabiq no. 9330, Nabi bersabda:

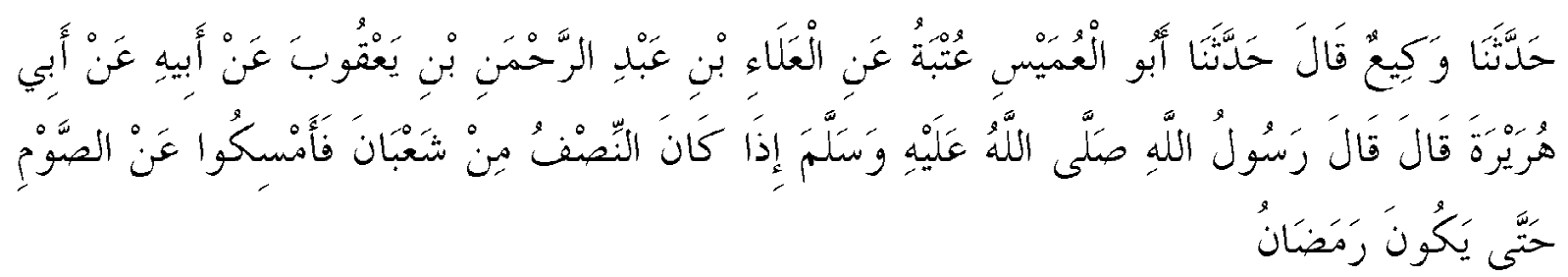

Artinya: Meriwayatkan kepada kami Waki', meriwayatkan kepada kami Abu al-Umais 'Utbah dari al-'Ala bin 'Abd al-Rahman bin Ya'qub dari ayatnya dari Abu Hurairah ia berkata, Rasulullah bersabda: Jika telah mencapai tengah bulan Sya'ban maka jangan kalian berpuasa bingga sampai bulan Ramadhan.

Hadis di atas bertentangan dengan hadis lainnya yang diriwayatkan oleh Aisyah dan Umm Salamah. Dalam Sahih Bukhari kitab al-ShaumbabShaum al-Sya'ban no. 1833 Nabi bersabda:

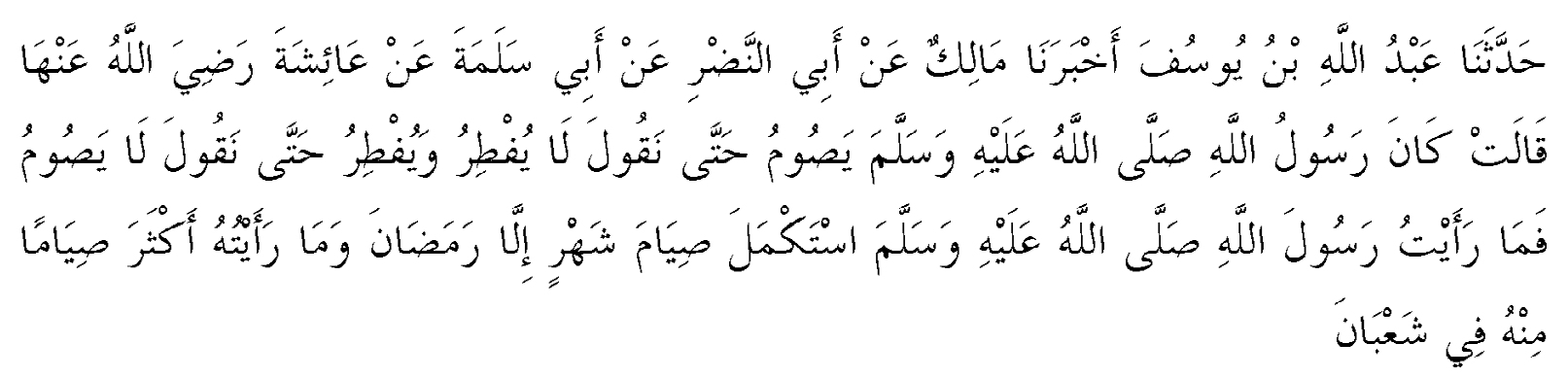

Artinya: Abd Allah telah meriwayatkan kepada kami, Malik meriwayatkan pada kami dari Abi al-Nadhar dari Abi Salamah dari Aisyah ra ia berkata: "Rasulullah sering berpuasa bingga kami mengira beliau tidak berbuka dan beliau berbuka puasa sebingga kami menduga beliau tidak berpuasa. Saya tidak pernah melihat Rasulullah menyempurnakan puasa selama satu bulan penub kecuali di bulan Ramadhan dan saya tidak pernah melihat beliau paling sering berpuasa kecuali pada bulan Sya'ban”.

Hadis Abu Hurairah di atas dinilai sendirian (tafarrud) oleh para ulama. Menurut mereka, rawi Al-'Ala ibn Abdurrahman meriwayatkannya secara sendiri dari ayahnya dari Abu Hurairah sedang ia adalah tsiqah. Imam Ahmad menilai hadis itu munkar karena hadisnya dhaif dan bertentangan dengan hadis dari jalur periwayat lain yang lebih sahih. ${ }^{24}$

\footnotetext{
${ }^{22}$ Shalah al-Din Ahmad al-Adlabi, Manhaj Naqd al-Matn, h. 273.

${ }^{23}$ Shalah al-Din Ahmad al-Adlabi, Manhaj Naqd al-Matn, h. 274.

${ }^{24}$ Shalah al-Din Ahmad al-Adlabi, Manbaj Naqd al-Matn, h. 291.
} 
Ketiga, riwayat yang bertentangan dengan akal, indera atau sejarah. Yang dimaksud dengan akal disini, menurut al-Adlabi adalah akal yang tercerahkan dengan al-Qur'an dan hadis yang sahih, bukan hanya akal semata, karena sesungguhnya akal saja tidak bisa menghukumi baik dan buruk. Hal ini berbeda dengan pandangan Mu'tazilah.

Berikut contoh hadis yang bertentangan dengan akal diriwayat oleh an-Nasai dalam kitab sunan Nasa'i kitab al-nikabbabtajwiz al-zaniah no. 3177. Hadis tersebut berbunyi:

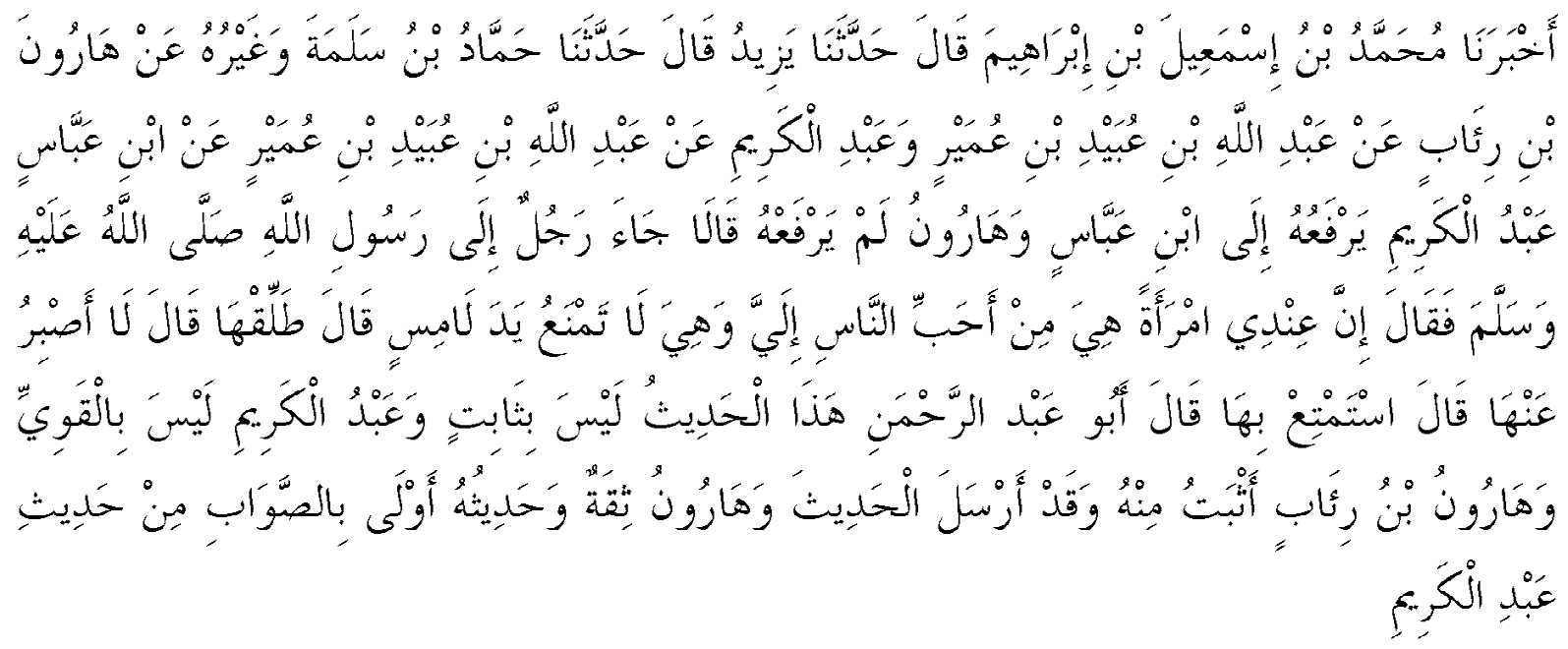

Artinya: Mengabarkan kepada kami Mubammad bin Ismail bin Ibrabim berkata, meriwayatkan pada kami Yazid ia berkata, meriwayatkan kepada kami Hammad bin Salamah dan yang lainnya dari Harun bin Ri'ab dari Abd Allah bin Ubaid bin 'Umair dan 'Abd al-Karim dari 'Abd Allah bin Ubaid bin 'Umair dari ibn 'Abbas, 'Abd al-Karim memarfu'kannya kepada Ibn 'Abbas dan Haun tidak memarfu'kannya. Keduanya berkata: "Seorang laki-laki datang kepada Rasulullah saw dan berkata: "sesunggubnya saya memiliki istri yang sangat saya cintai, tetapi ia tidak menolak tangan orang yang menyentuhnya". Rasul bersabda: "talaklah dia". Laki-laki tersebut berkata: "Saya tak dapat berpisah darinya". Rasul bersabda: "Bersenang-senanglah dengannya". Abu 'Abd al-Rabman berkata: "Hadis ini tidaklah kuat dan 'Abd al-Karim dinilai tidak kuat hafalannya, sedang harun bin Ri'ab lebih kuat darinya namun telah memursalkan hadis. Harun merupakan perawi yang tsiqah dan hadisnya lebih sabih dibanding hadis riwayat 'Abd al-Karim. (HR. Nasa'i).

Ungkapan 'ia tidak menolak tangan orang yang menyentubnya', menurut al-Adlabi mengandung pengertian lacur. Meski sebagian ulama mena'wilkannya ungkapan di atas dengan pengertian lain, seperti 'ia tidak menolak tangan orang yang mengajaknya bersalaman walaupun bukan mubrimnya'. Namun, ta'wil seperti ini, menurut al-Adlabi, tidak dapat dibenarkan secara bahasa. Sekiranya ta'wil tersebut benar maka tidak mungkin Rasulullah menyuruhnya untuk tetap menahan perempuan tersebut sebagai istrinya. Sedang Imam Ahmad bin Hanbal telah menganggap hadis ini tidak berasal dari Rasul dan tidak punya asal. Ibn al-Jauzi juga menempatkan hadis ini dalam kitab Maudhu'at. ${ }^{25}$

Keempat, tidak mirip dengan sabda kenabian. Terkadang suatu riwayat berasal dari Rasul, tidak bertentangan dengan nash al-Qur'an atau sunnah yang sahih, akal, indera (kenyataan), atau sejarah, tetapi riwayat tersebut tidak seperti perkataan kenabian, maka tidak dapat diterima.

Menurut al-Adlalbi, para ulama memang sulit untuk menentukan perkataan mana yang tidak seperti perkataan kenabian, tetapi yang terpenting adalah perkataan yang mengandung keserampangan,

${ }^{25}$ Shalah al-Din Ahmad al-Adlabi, Manhaj Naqd al-Matn, h. 306. 
atau makna-makna yang rendah, atau ungkapan tentang istilah-istilah yang datang kemudian. Ia kemudian membagi pembahasan menjadi tiga bentuk yakni:

1. Hadis-hadis yang mengandung keserampangan

2. Hadis-hadis yang mengandung makna yang rendah.

3. Hadis-hadis yang lebih menyerupai perkataan ulama khalaf.

Berikut adalah contoh hadis yang mengandung makna serampangan. Hadis tersebut riwayat Ibn Majah dalam kitab sunannya kitab al-tijaratbabal-taglid fi al-riba no. 2265. Hadis tersebut berbunyi:

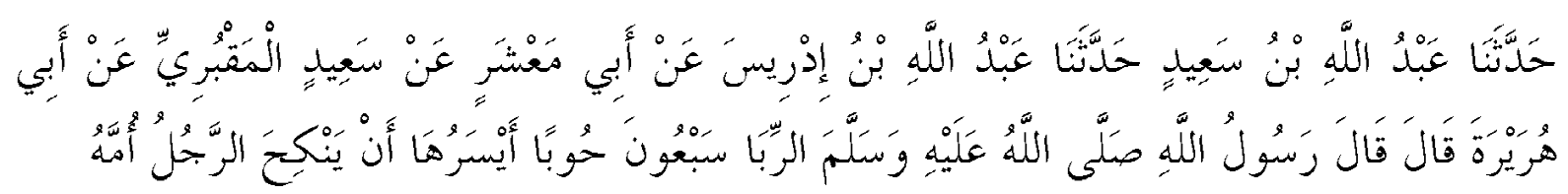

Artinya: Meriwayatkan kepada kami 'Abd Allab bin Sa'id, meriwayatkan pada kami 'Abd Allah bin Idris dari Abi Ma'syar dari Sa’id al-Maqburi dari Abu Hurairah ia berkata, Rasulullah saw bersabda: Riba memiliki 70 macam dosa dan dosa yang paling ringan adalah seperti seseorang menikabi ibunya sendiri. (HR. Ibn Majah).

Menurut al-Adlabi, hadis ini jelas mengandung unsur terlalu berlebihan dalam memberi peringatan. Seandainya riba termasuk salah satu dosa besar dan seandainya Allah mengizinkan memerangi pemahan riba, maka haruskah dosa terendahnya adalah seperti dosa menikahi ibunya?

Menurutnya, mungkin saja perkataan ini diambil dari perkataan yang mauquf kepada Ka'ab ibn Mati', yaitu: Berzina sebanyak tiga pulub tiga kali lebih aku sukai dibanding memakan satu dirham secara riba yang Allah tahu aku memakannya secara riba'. Tidak diragukan lagi bahwa para pemalsu telah mengambil hadis itu dari perkataan mauquf ini dengan memberikan tambahan-tambahan. ${ }^{26}$

\section{Kajian Kritis Terhadap Metode Kritik Matan Al-Adlabi}

Para ulama hadis menyatakan bahwa tolok ukur yang dikembangkan dalam studi kritik matan hadis tidak lepas dari unsur-unsur kaedah kesahehan hadis yang telah ditetapkan ulama terdahulu. Dalam aspek matan, mereka menyatakan bahwa hadis yang sahih adalah hadis yang terbebas dari unsur syadz dan illah.

Sebagaimana disebutkan di atas, Arifuddin Ahmad, menyebutkan beberapa unsur kaedah minor syadz pada matan, diantaranya 1. Sanad hadis bersangkutan tidak menyendiri; 2. Matan hadis bersangkutan tidak bertentangan dengan matan hadis yang sanadnya lebih kuat; 3 matan hadis bersangkutan tidak bertentangan dengan al-Qur'an; dan 4. Matan hadis bersangkutan tidak bertentangan dengan akal dan fakta sejarah.

Sedang kaedah minor bagi matan hadis yang mengandung "illah adalah 1. Matan hadis bersangkutan tidak mengandung idraj (sisipan); 2. Matan hadis bersangkutan tidak mengandung ziyadah (tambahan); 3. Tidak terjadi maqlub (pergantian lafal atau kalimat) bagi matan hadis bersangkutan; 4. Tidak terjadi idhthirab (pertentangan yang tidak dapat dikompromikan) bagi matan hadis bersangkutan; dan 5. Tidak terjadi kerancuan lafal dan penyimpangan makna yang jauh dari matan hadis bersangkutan.

Dengan demikian, bila tolok ukur kritik matan hadis versi al-Adlabi yang mencakup empat unsur sebagaimana disebutkan di atas ditempatkan pada dua kaedah kesahihan hadis yang tidak

${ }^{26}$ Shalah al-Din Ahmad al-Adlabi, Manhaj Naqd al-Matn, h. 335. 
mengandung syadz dan 'illah di atas, maka dapat disimpulkan bahwa tolok ukur tersebut hanya mencakup unsur kaedah minor syadz matan hadis dan tidak memuat kaedah minor unsur "illah. Karenanya, Syuhudi Ismail memasukkan tolok ukur kritik matan al-Adlabi sebagai salah bentuk aplikatif dari kaedah kesahihan matan yang merupakan bagian dari metodologi penelitian matan. Menurut Syuhudi, ada tiga langkah metodologis yang digunakan dalam penelitian matan yakni: pertama, meneliti matan dengan meneliti sanadnya. Kedua, meneliti susunan lafal berbagai matan yang semakna dan ketiga, meneliti kandungan matan. ${ }^{27}$ Langkah pertama merupakan bidang kajian penelitian sanad hadis, langkah kedua merupakan penelitian aspek illah matan hadis sedang langkah ketiga adalah penelitian aspek syadz pada matan hadis.

Sedang bagi al-Adlabi sendiri, sesungguhnya para ulama hadis belum merinci secara mendetail unsur-unsur kritik matan dalam kaedah kesahehan hadis terutama unsur syadz dan illah. Menurutnya, kaedah kritik matan tersebar dalam berbagai bahasan mengenai ilmu hadis termasuk dalam hal mengenal hadis maudbu' dan tidak bisa dipaksakan untuk masuk dalam kaedah minor syadz dan 'illah dalam kritik matan hadis. Berdasarkan hal tersebut, ia berusaha menggabungkan berbagai unsur kaedah kritik matan yang terdapat dalam kajian ilmu hadis sebagai landasan bagi metode kritik matannya. Ataukah al-Adlabi sebenarnya ingin mengatakan bahwa ilmu hadis tidak cukup dalam meneliti matan sehingga memerlukan kaedah tersendiri yang terpisah dari rumusan-rumasan baku ilmu hadis atau ini hanya sekadar upaya reformulasi ilmu hadis di bidang kritik matan?

\section{Penutup}

Dalam meneliti matan hadis, para ulama memasukkannya dalam kajian kaedah matan yang mencakup unsur syadz dan 'illah. Syadz pada matan dipahami sebagai pertentangan antara hadis yang sahih dengan dalil-dalil lain yang lebih sahih baik al-Qur'an, hadis mutawatir, akal dan fakta sejarah. Sedang 'illah pada matan mencakup idraj (sisipan, ziyadah (tambahan), maqlub (pergantian lafal atau kalimat), idhthirab (pertentangan yang tidak dapat dikompromikan) dan kerancuan lafal dan penyimpangan makna yang jauh dari matan hadis bersangkutan. Di samping unsur kaedah minor pada syadz dan 'illah matan hadis, para ulama juga menetapkan ciri-ciri khusus yang berkaitan dengan hadis maudhu', kriteria hadis maqbul dan tolok ukur kritik matan hadis.

Al-Adlabi menetapkan empat kriteria kritik matan hadis yakni 1. Tidak bertentangan dengan al-Qur'an al-Karim, 2. Tidak bertentangan dengan hadis dan sirah nabawiyah yang sahih, 3. Tidak bertentangan akal, indera dan sejarah, 4. Tidak mirip dengan sabda kenabian. Apabila terdapat salah satu dari kriteria tersebut dalam matan hadis maka dapat diyatakan tidak sahih hadisnya.

Dalam aplikasi teori kritik matan hadisnya, al-Adlabi memberikan contoh hadis yang bertentangan dengan kandungan al-Qur'an, sirah nabawiyah, akal, indera atau sejarah, dan yang tidak hadis yang tidak mirip dengan sabda kenabian.

\section{Daftar Pustaka}

Aan Supiyan, (1995). Konsep Syadz dan Illat: Kriteria Kesabihan Matan Hadis, Jakarta, Studia Press.

Ahmad Amin, (1974). Dhuba al-Islam, Kairo, Maktabah al-Nahdhah al-Mishriyyah. 
Arifuddin Ahmad, (2005). Paradigma Baru Memahami Hadis Nabi: Refleksi Pemikiran Pembaruan Prof. Dr. Mubammad Syubudi Ismail, Jakarta, MSCC.

Bustamin dan M. Isa H.A. Salam, (2004). Metodologi Kritik Hadis, Jakarta, Raja Grafindo Persada.

CD-ROM (1997). Mausu'ah al-Hadis al-Syarif al-Kutub al-Tis'ah.

Hamzah Abu al-Fath bin Husain Qasim al-Na'imi, (1999). al-Manhaj al-Tlmy li al-Ta'amul ma'a alSunnah al-Nabawiyyah Inda al-Muhadditsin, Ordon, Dar al-Nafais.

Hasjim Abbas, (2004). Kritik Matan Hadis versi Muhaddisin dan Fuqaha, Yogyakarta, Teras.

Ibn Shalah, (1979). Muqaddimah Ibn Shalah fi 'Ulum al-Hadis, Beirut, Dar al-Kutub al-'Tlmiyyah.

Mahmud al-Thahhan, (tth). Taysir Mushthalah al-Hadits, Beirut, Dar al-Fikr.

Muhammad 'Ajaj al-Khatib, (1993). al-Sunnah Qabla al-Tadwin, Beirut, Dar al-Fikr.

—, (1989). Ushul al-Hadis: 'Ulumuhu wa Mushthalahuhu, Beirut, Dar al-Fikr.

Muhammad Hasbi ash-Shiddieqy, (1997). Sejarah dan Pengantar Ilmu Hadis, Semarang, Pustaka Rizki Putra.

Muhammad Muhammad Abu Zahwu, (tth). al-Hadis wa al-Muhadditsun, Beirut, Dar al-Fikr al-'Araby.

M. Syuhudi Ismail, (1992). Metodologi Penelitian Hadis Nabi, Jakarta, Bulan Bintang.

Nur al-Din 'Itr, (1997). Manbaj al-Naqd fi Ulum al-Hadis, Beirut, Dar al-Fikr, th, diterjemahkan oleh Mujiyo, 'Ulum al-Hadit, Bandung, Rosdakarya.

Shalah al-Din Ahmad al-Adlabi, (1983). Manhaj Naqd al-Matn Inda Ulama al-Hadis al-Nabawi, Beirut, Dar al-Afaq al-Jadid.

Shubhi al-Shalih, (1988). 'Ulum al-Hadis wa Mushthalahuhu, Beirut, Dar al-'Ilm li al-Malayin al-Suyuthiy, (1988). Tadrib al-Rawi fi Syarb Taqib al-Nawawi, Juz I, Beirut, Dar al-Fikr. 